\title{
ACUTE KIDNEY INJURY AFTER OPEN-HEART SURGERY PROCEDURES
}

\author{
Anže Djordjević ${ }^{1}$, Stamenko Šušak ${ }^{2,3}$, Lazar Velicki $^{2,3}$ and Miha Antonič ${ }^{1,4}$ \\ ${ }^{1}$ Maribor University Medical Center, Department of Cardiac Surgery, Maribor, Slovenia; \\ ${ }^{2}$ Institute of Cardiovascular Diseases of Vojvodina, Department of Cardiovascular Surgery, Sremska Kamenica, Serbia; \\ ${ }^{3}$ University of Novi Sad, Faculty of Medicine, Novi Sad, Serbia; \\ ${ }^{4}$ University of Maribor, Faculty of Medicine, Maribor, Slovenia
}

\begin{abstract}
SUMMARY - Cardiac surgery-associated acute kidney injury (CS-AKI) is a major complication associated with increased morbidity and mortality. There are multiple diagnostic criteria for CS-AKI. Despite many new investigations available for improved AKI diagnostics, creatinine and urea remain the cornerstone of diagnostics in everyday clinical practice. There are three major pathophysiological mechanisms that contribute to kidney injury, i.e. renal hypoperfusion, inflammation with oxidative stress, and use of nephrotoxic agents. Some risk factors have been identified that can be modified during the course of treatment (use of nephrotoxic agents, duration of cardiopulmonary bypass, type of extracorporeal circulation, postoperative low cardiac output or hypotension). The aim of AKI prevention should always be to prevent aggravation of renal failure and, if possible, to avoid progression to renal replacement therapy, which in turn brings worse long-term outcomes.
\end{abstract}

Key words: Kidney injuries; Cardiac surgery; Perfusion; Oxidative stress; Dialysis

\section{Introduction}

Acute kidney injury (AKI) is one of the most prevalent major complications following open-heart surgery $^{1}$. Its incidence ranges from $5 \%$ to $42 \%$, depending on diagnostic criteria and population studied ${ }^{2}$. It is clinically important because of higher perioperative mortality (up to 3- to 8-fold), prolonged intensive care unit (ICU) stay, and increased costs ${ }^{3-5}$. Even subtle decrease in renal function could potentially be associated with increased mortality, especially after previous percutaneous coronary interventions ${ }^{6}$. In the ICU, AKI after cardiac surgery (CS-AKI) represents the second most common cause of all-cause AKI, just after sepsis ${ }^{7}$. CS-AKI is a type 1 representative of the 'cardiorenal syndrome', a condition in which acute failure of one

Correspondence to: Anže Djordjević, $M D$, Maribor University Medical Center, Department of Cardiac Surgery, Ljubljanska ulica 5, 2000 Maribor, Slovenia

E-mail: anze.djordjevic@ukc-mb.si

Received February 10, 2020, accepted August 18, 2020 organ deteriorates the function of another one. Classification of cardiorenal syndrome has been proposed by Ronco et al. in 2008 and has five types (Table 1$)^{8}$.

\section{Diagnostic Criteria}

There are over 30 AKI definitions found in the literature; however, clinically the most widely used classifications are the following:

- Risk, Injury, Failure, Loss of kidney function and End-stage renal failure (RIFLE) ${ }^{9}$;

- Acute Kidney Injury Network (AKIN) ${ }^{10}$; and

- Kidney Disease: Improving Global Outcomes (KDIGO) ${ }^{11}$ (Table 2).

Although numerous new biomarkers (cystatin C, neutrophil gelatinase-associated lipocalin, interleukins 6 and 18, kidney injury molecule-1, liver-type fatty acid binding protein, $\mathrm{N}$-acetyl- $\beta-\mathrm{D}$-glucosaminidase, $\alpha 1$ microglobulin, glutathione transferase- $\pi$, tissue inhibitor of metalloproteinase 2, insulin-like growth factor-binding protein 7$)^{13-15}$ have been investigated 
Table 1. Cardiorenal syndrome $e^{8}$

\begin{tabular}{|l|l|l|l|}
\hline Type & Inciting event & Secondary disturbance & Example \\
\hline Type 1 & $\begin{array}{l}\text { Rapid worsening of cardiac } \\
\text { function } \\
\text { Type 2 } \\
\text { functionic abnormalities in cardiac }\end{array}$ & Acute kidney injury & $\begin{array}{l}\text { Acute cardiogenic shock or acute } \\
\text { decompensation } \\
\text { Typegressive chronic kidney injury } \\
\text { Chronic heart failure }\end{array}$ \\
Type 4 & $\begin{array}{l}\text { function } \\
\text { Chronic kidney disease }\end{array}$ & $\begin{array}{l}\text { Acute heart failure or arrhythmia } \\
\text { Decreased cardiac function, } \\
\text { ventricular hypertrophy } \\
\text { Combined cardiac and renal } \\
\text { dysfunction }\end{array}$ & Acute kidney injury \\
Type 5 & $\begin{array}{l}\text { Acute or chronic systemic } \\
\text { disorder }\end{array}$ & $\begin{array}{l}\text { Chronic glomerular disease } \\
\text { vasculitis, sarcoidosis }\end{array}$ \\
\hline
\end{tabular}

Table 2. Comparison of acute kidney injury classifications ${ }^{12}$

\begin{tabular}{|c|c|c|c|c|c|}
\hline \multicolumn{2}{|l|}{ RIFLE } & \multicolumn{2}{|l|}{ AKIN } & \multicolumn{2}{|l|}{ KDIGO } \\
\hline Criterion & Creatinine definition & Criterion & Creatinine definition & Criterion & Creatinine definition \\
\hline Risk & $\begin{array}{l}\geq 1.5 \text {-fold baseline } \\
\text { SCr increase or } \geq 25 \% \\
\text { GFR decrease }\end{array}$ & Stage 1 & $\begin{array}{l}\geq 1.5 \text {-fold or } \geq 26.5 \\
\mu \mathrm{mol} / \mathrm{L} \text { baseline } \mathrm{SCr} \\
\text { increase within } 48 \mathrm{~h}\end{array}$ & Stage 1 & $\begin{array}{l}\geq 1.5 \text {-fold baseline } \mathrm{SCr} \\
\text { increase within } 7 \mathrm{~d} \text { or } \\
\geq 26.5 \mu \mathrm{mol} / \mathrm{L} \text { within } 48 \mathrm{~h}\end{array}$ \\
\hline Injury & $\begin{array}{l}\geq 2 \text {-fold baseline } \\
\text { SCr increase or } \geq 50 \% \\
\text { GFR decrease }\end{array}$ & Stage 2 & $\begin{array}{l}\geq 2 \text {-fold baseline } \\
\mathrm{SCr} \text { increase }\end{array}$ & Stage 2 & $\begin{array}{l}\geq 2 \text {-fold baseline } \mathrm{SCr} \\
\text { increase within } 7 \mathrm{~d}\end{array}$ \\
\hline Failure & $\begin{array}{l}\geq 3 \text {-fold baseline } \\
\text { SCr increase or } \geq 75 \% \\
\text { GFR decrease or } \\
\mathrm{SCr} \geq 353.6 \mu \mathrm{mo} / \mathrm{L}\end{array}$ & Stage 3 & $\begin{array}{l}\geq 3 \text {-fold or } \geq 44.2 \\
\mu \mathrm{mol} / \mathrm{L} \text { baseline } \\
\mathrm{SCr} \text { increase or RRT } \\
\text { initiation }\end{array}$ & Stage 3 & $\begin{array}{l}\geq 3 \text {-fold baseline } \mathrm{SCr} \\
\text { increase within } 7 \mathrm{~d} \text { or } \mathrm{SCr} \\
\geq 353.6 \mu \mathrm{mol} / \mathrm{L} \text { or } \mathrm{RRT} \\
\text { initiation }\end{array}$ \\
\hline Loss & RRT >4 weeks & & & & \\
\hline End stage & RRT $>3$ months & & & & \\
\hline
\end{tabular}

$\mathrm{SCr}=$ serum creatinine; GFR = glomerular filtration rate; RIFLE = Risk, Injury, Failure, Loss of kidney function and End-stage renal failure; AKIN = Acute Kidney Injury Network; KDIGO = Kidney Disease: Improving Global Outcomes; RRT = renal replacement therapy

for more accurate AKI diagnosis, the most frequently used and recommended by the Acute Disease Quality Initiative (ADQI) Group still are creatinine and urea ${ }^{16}$.

Creatinine is a metabolic product of creatine phosphate breakdown in the skeletal muscle metabolism. Its usefulness comes from a relatively constant secretion rate through glomerular filtration, whereas on the other hand, none of it is reabsorbed. The main disadvantage is its dependence on muscle mass (more substrate for phosphorylation through creatine kinase), muscular rhabdomyolysis or medication intake (cimetidine, trimethoprim-sulfamethoxazole or probenecid ${ }^{17}$. Blood tests for creatinine are significantly cheaper compared to other biomarkers listed above.
Urea is one of the nitrogen metabolism products, which is formed mainly from amino acids. Urea transports nitrogen and thus creates osmotic gradient for water reabsorption in the loop of Henle. Its main disadvantage is responding to external kidney unrelated factors such as weight loss (increased proteolysis, more amino acids, more nitrogen) and dehydration (excessive need for water reabsorption) $)^{18}$.

\section{Pathophysiology}

The mechanisms that influence CS-AKI are not yet fully understood. They could be distinguished into three major groups, as follows: 
- renal hypoperfusion (prerenal AKI);

- inflammation and oxidative stress (renal AKI); and

- nephrotoxic medications and agents (renal AKI $)^{19,20}$.

\section{Renal hypoperfusion}

Renal hypoperfusion is the consequence of nonpulsatile low-flow circulation state during surgery maintained by extracorporeal circulation (ECC). In addition, fast temperature changes are observed during surgery, which in turn affect renal flow. The latter could also be compromised by excessive intraoperative bleeding. Open-heart procedures often present a state of unstable cardiac output, and since the kidneys take up to $20 \%$ of cardiac output, any decrease in cardiac output (either through increased resistance or decreased pressure gradient) will eventually compromise renal flow. Prolonged kidney ischemia leads to acute tubular necrosis, since the proximal tubule is one of the most metabolically active tissues and consequently sensitive to oxygen deprivation. After ECC termination, ischemia-reperfusion injury (IRI) can decrease cellular energy storage with direct mitochondrial damage and oxidative phosphorylation reduction. On the other hand, IRI causes massive influx of reactive oxygen species (ROS). Intravascular hemolysis occurs after blood contacting artificial surfaces in the ECC circuit, thus liberating hemoglobin, which leads to nitric oxide suppression, afferent arterial vasoconstriction, and increased heme oxygenase 1 expression $^{21}$.

\section{Inflammation and oxidative stress}

Surgical tissue injury and blood exposure to artificial materials coupled with blood transfusions cause massive inflammatory cell accumulation and complement activation. The main factor in ROS creation is the iron accumulated from hemoglobin release. It affects renal cell proliferation via lipid peroxidation and/ or protein oxidation ${ }^{22}$.

\section{Nephrotoxic medications and agents}

Kidney function is also affected by various xenobiotics, frequently used pre-, intra- and postoperatively. The main groups are antibiotics (glycopeptides, aminoglycosides), nonsteroidal anti-inflammatory drugs and antihypertensive drugs (angiotensin-converting enzyme inhibitors, angiotensin receptor blockers). Major impact of contrast dye (used in many diagnostic procedures) on kidney injury has been proven, as it is used for some diagnostic procedures (coronary angiography, computed tomography). A response via the sympathetic nervous system is triggered, resulting in renin-angiotensin-aldosterone axis activation and increased vasopressin and endothelin production, all leading to afferent arterial vasoconstriction and diminished renal flow. In patients with infective endocarditis, septic emboli are frequent, which can also lead to tubular necrosis. A similar effect can be observed after cholesterol emboli due to extensive aortic manipulation $^{23}$.

Regardless of the mechanism, CS-AKI can also be classified according to the onset timing into early AKI (in the first seven days after surgery) and late AKI (in more than seven days after surgery, most frequently after cardiogenic shock) ${ }^{20}$.

\section{Acute Kidney Injury Risk Factors}

Wang and Bellomo have divided risk factors by their relevance at different times with respect to the cardiac surgery procedure $\mathrm{e}^{20}$. Preoperative risk factors include female sex, advanced age, pre-existing comorbidities (chronic kidney disease (CKD), previous cardiac surgery, diabetes mellitus (DM), chronic obstructive pulmonary disease, arterial hypertension, hypercholesterolemia, congestive heart failure, left ventricular ejection fraction $<35 \%$, and obesity $)^{24}$. Intraoperative factors include use of nephrotoxic medications, emergency surgery, cardiopulmonary bypass $(\mathrm{CPB})$ time, and complexity of surgery ${ }^{25}$. Postoperative risk factors include postoperative hypotension/cardiogenic shock, low hematocrit $(<24 \%)$, and need for blood transfusion ${ }^{26}$.

However, risk factors could also be classified according to the possible impact they could have in order to prevent CS-AKI. The non-modifiable factors are female sex, advanced age, pre-existing comorbidities, emergency surgery, and complexity of surgery. The factors that could be at least potentially influenced are preoperative obesity in patients undergoing elective procedures, nephrotoxic substance use, CPB time, cross-clamp time, non-pulsatile flow, and intraoperative or postoperative bleeding.

The role of CPB is still controversial. There have been only three randomized controlled trials compar- 
ing on-pump versus off-pump coronary artery bypass grafting $(\mathrm{CABG})$ surgeries. The CORONARY trial was conducted on 4752 patients in 79 centers worldwide, who were randomly assigned to off-pump or onpump CABG. At one year after surgery, no reduction in mortality, myocardial infarction, stroke or new renal failure requiring renal replacement therapy (RRT) was observed $^{27}$. The ROOBY trial enrolled 2203 patients in 18 centers, who were randomly chosen for either off-pump or on-pump CABG. Interestingly, some differences proved to be statistically significant in perioperative data, such as residents being the primary surgeons' $(\mathrm{p}<0.001)$, conversion to other treatment $(p<0.001)$, duration of surgery $(p=0.05)$, number of grafts performed, and ratio between the number of planned and performed grafts $(\mathrm{p}<0.001)$, all in favor of on-pump CABG. There were no differences regarding renal failure at 30-day follow-up, including renal failure requiring RRT. Unfortunately, no data on renal function after one year are reported ${ }^{28}$. In the HEPCON trial, which included 120 patients, Deininger et al. compared three different types of $\mathrm{CPB}$, i.e. conventional $\mathrm{CPB}$, minimally invasive $\mathrm{CPB}$, and off-pump CABG. Temporary superiority of minimally invasive $\mathrm{CPB}$ and off-pump surgery was recorded in regard to acute tubular necrosis via free hemoglobin measurement $(p<0.001)$, but with no significant long-term differences ${ }^{29}$.

\section{Prediction}

The ADQI Group recommends routine implementation of risk-prediction models for all cardiac surgical procedures, using estimated glomerular filtration rate (eGFR), cystatin $\mathrm{C}$ or albuminuria to predict postoperative $\mathrm{AKI}^{16}$. The Cleveland Clinic Score, the Mehta Score and the Simplified Renal Index score are all validated scores in predicting AKI, especially severe AKI prone to $\mathrm{RRT}^{30-32}$. Of all the predicting scores for severe AKI, the Cleveland Clinic Score is most widely tested and showed high discrimination in the tested cohorts $^{33}$. Birnie et al. developed a KDIGO-based score to predict AKI of all stages, not only severe AKI. The following independent risk factors for developing end-stage AKI have been identified: age $>75$ years, female sex, body mass index $(B M I)>35$, active smoking status, New York Heart Association (NYHA) class 4, preoperative DM, arterial hypertension, and GFR >90
$\mathrm{mL} / \mathrm{min}^{34}$. Taking into account the high risk of AKI development, using the Reynolds Risk Score can predict the overall cardiovascular risk ${ }^{35}$.

\section{Prevention and Therapy}

There are some useful principles for optimal postoperative patient management, as follows:

- low cardiac output avoidance with the use of inotropes and blood volume substitution (hematocrit $>24 \%$, role of pulsatile CPB is still controversial);

- hypotension avoidance with optimal volume management and vasopressors (mean arterial pressure (MAP) $>60 \mathrm{~mm} \mathrm{Hg}$, use of balanced solutions over $0.9 \%$ saline to prevent hyperchloremia;

- nephrotoxic agent avoidance; and

- glycemic index optimization (blood glucose <6.1 $\mathrm{mmol} / \mathrm{L})^{12,16,20}$.

Nevertheless, even with optimal management, 2\%-6\% of patients develop severe AKI for which RRT must be initiated ${ }^{23}$. RRT initiation criteria are as follows:

- clinical: anuria $\geq 6 \mathrm{~h}$ or urine output $\leq 200 \mathrm{~mL}$ over $12 \mathrm{~h}$ or volume overload (pulmonary edema unresponsive to diuretics); and

- laboratory: hyperkalemia $>6.5 \mathrm{mmol} / \mathrm{L}$ or metabolic acidosis $\mathrm{pH}<7.2$ or urea $>30 \mathrm{mmol} / \mathrm{L}$ or creatinine $>300 \mu \mathrm{mol} / \mathrm{L}^{36}$.

Many preventive measures were investigated in recent years. Antonic reports no significant reduction in CS-AKI using perioperative intravenous antioxidant ascorbic acid $(\mathrm{p}=0.779)$. However, it was a small, single-center study enrolling only 100 elective low-risk on-pump CABG patients ${ }^{37}$. Bailey et al. investigated a potential renoprotective effect of urine alkalization using sodium bicarbonate through decreased complement activation and prevention of tubular hemoglobin cast formation. Performing a meta-analysis on 877 patients from three double-blind randomized controlled trials, they demonstrated only reduction in severe AKI development and RRT avoidance ( $\mathrm{p}<0.001)$, but no statistical significance was achieved in overall AKI $(p=0.29)^{38}$. Yang et al. proved osmotic agent mannitol involvement in renal function decrease in patients with contrast-induced nephropathy, with no beneficial effects regarding CS-AKI in their meta-analysis con- 
taining 626 patients from nine randomized controlled trials $(\mathrm{p}=0.59)^{39}$. Scrascia et al. conducted a meta-analysis on 931 patients in 14 trials in regards to steroid use in cardiac surgery patients in order to modulate inflammatory response, but were unsuccessful in proving its beneficial effect $(p=0.79)^{40}$. The ADQI Group does not recommend levosimendan, statins, and Nacetylcysteine ${ }^{16}$.

\section{Minimally Invasive Cardiac Surgery and Renal Function}

Although the incidence of minimally invasive approaches for cardiac surgery procedures is increasing, literature covering the topic of AKI after these procedures is scarce. A recent study by Vandewiele et al. found no important clinical differences in renal function between minimally invasive cardiac surgery (MICS) and conventional median sternotomy with mitral and/or tricuspid valve surgery despite longer $\mathrm{CPB}$ and aortic cross-clamp times in the MICS group ${ }^{41}$. In the aortic valve position, comparison between MICS and transaortic transcatheter aortic valve implantation (TAVI) revealed a higher risk of AKI development in the TAVI group $(\mathrm{p}=0.017)$, with higher preoperative EuroSCORE II having no impact on postoperative $\mathrm{AKI}^{42}$. Left ventricular assist devices (LVADs) significantly improve kidney function with a trend towards better renal outcomes after MICS but with no statistical significance due to a small group size $\mathrm{e}^{43}$.

\section{Conclusion}

Cardiac surgery-associated acute kidney injury remains a serious complication after cardiac surgery with a high incidence and clinically important short- and long-term consequences, especially in patients requiring RRT. Sixty-day mortality of patients requiring RRT after cardiac surgical procedures exceeds $50 \%{ }^{44}$. Short-term consequences of CS-AKI are uremia (increased capillary permeability, increased risk of bleeding, altered mental status), electrolyte imbalance (dysrhythmias, muscular weakness, altered mental status), acid-base imbalance (increased proteolysis, hemodynamic instability), and volume overload (interstitial edema, increased intraabdominal pressure, disturbed oxygen diffusion) $)^{20,44-47}$. Long-term consequences of CS-AKI are deterioration of pre-existing CKD (with a trend towards a higher risk of developing postpericardiotomy syndrome ${ }^{48}$ ) with increased hospital readmission rate with the Major Adverse Kidney Events composite adaptation, consisting of $>25 \%$ eGFR reduction, RRT or death, which could in case of impairment after 90 days meet the criterion for $\mathrm{CKD}^{49}$; increased mortality (Ferreiro et al. proved a transient association of CS-AKI with long-term mortality that progressively decreases and vanishes five years after surger $y^{50}$ ); decreased quality of life; and increased risk of further cardiovascular events ${ }^{20,44-47}$.

\section{References}

1. Bove T, Monaco F, Covello RD, Zangrillo A. Acute renal failure and cardiac surgery. HSR Proc Intensive Care Cardiovasc Anesth. 2009;1(3):13-21.

2. Hobson CE, Yavas S, Segal MS, Schold JD, Tribble CG, Layon $\mathrm{AJ}$, et al. Acute kidney injury is associated with increased long-term mortality after cardiothoracic surgery. Circulation. 2009;119(18):2444-53. DOI: 10.1161/CIRCULATIONAHA.108.800011

3. Golubović M, Mihajlović B, Kovačević P, Cemerlić-Adjić N, Pavlović K, Velicki L, et al. Postoperativne neletalne komplikacije nakon operacije na otvorenom srcu. Vojnosanit Pregl. 2012;69(1):27-31. DOI: 10.2298/VSP1201027G (in Serbian)

4. Hobson C, Ozrazgat-Baslanti T, Kuxhausen A, Thottakkara P, Efron PA, Moore FA, et al. Cost and mortality associated with postoperative acute kidney injury. Ann Surg.2015;261(6):120714. DOI: $10.1097 /$ SLA.0000000000000732

5. Ortega-Loubon C, Fernandez-Molina M, Carrascal-Hinojal Y, Fulquet-Carreras E. Cardiac surgery-associated acute kidney injury. Ann Card Anaesth. 2016;19(4):687-98. DOI: 10.4103/0971-9784.191578

6. Kanic V, Penko M, Naji FH, Ekart R, Kanic Z, Dinevski D, et al. Deterioration of renal function at stent implantation can predict long-term outcome after stent thrombosis. Wien Klin Wochenschr. 2015;127:181-6. DOI: 10.1007/s00508-0150844-1

7. Mao H, Katz N, Ariyanon W, Blanca-Martos L, Adybelli Z, Giuliani A, et al. Cardiac surgery-associated acute kidney injury. Cardiorenal Med. 2013;3(3):178-99. DOI: 10.1159/ 000353134

8. Ronco C, Haapio M, House AA, Anavekar N, Bellomo R. Cardiorenal syndrome. J Am Coll Cardiol. 2008;52(19):152739. DOI: 10.1016/j.jacc.2008.07.051

9. Bellomo R, Ronco C, Kellum JA, Mehta RL, Palevsky P, the ADQI workgroup. Acute renal failure - definition, outcome measures, animal models, fluid therapy and information technology needs: The Second International Consensus Conference of the Acute Dialysis Quality Initiative (ADQI) Group. Crit Care. 2004;8(4):204-12. DOI: 10.1186/cc2872 
10. Mehta RL, Kellum JA, Shah SV, Molitoris BA, Ronco C, Warnock DG, et al. Acute Kidney Injury Network: report of an initiative to improve outcomes in acute kidney injury. Crit Care. 2007;11(2):31. DOI: 10.1186/cc5713

11. Kellum JA, Lameire N. KDIGO Clinical Practice Guideline for acute kidney injury 2012. Kidney Int Suppl. 2012;2:1-138. DOI: $10.1038 /$ kisup. 2012.1

12. Shin SR, Kim WH, Kim DJ, Shin IW, Sohn JT. Prediction and prevention of acute kidney injury after cardiac surgery. Biomed Res Int. 2016; ID 2985148. DOI: 10.1155/2016/2985148

13. Prowle JR, Calzavacca P, Licari E, Ligabo EV, Echeverri JE, Bagshaw SM, et al. Combination of biomarkers for diagnosis of acute kidney injury after cardiopulmonary bypass. Ren Fail. 2015;37(3):408-16. DOI: 10.3109/0886022X.2014.1001303

14. Lu JCT, Coca SG, Patel UD, Cantley L, Parikh CR. Searching for genes that matter in acute kidney injury: a systematic review. Clin J Am Soc Nephrol. 2009;4(6):1020-31. DOI: 10.2215/CJN.05411008

15. O'Neal JB, Shaw AD, Billings FT. Acute kidney injury following cardiac surgery: current understanding and future directions. Crit Care. 2016;20:187. DOI: 10.1186/s13054-0161352-z

16. Nadim MK, Forni LG, Bihorac A, Hobson C, Koyner JL, Shaw A, et al. Cardiac and Vascular Surgery-Associated Acute Kidney Injury: The $20^{\text {th }}$ International Consensus Conference of the ADQI (Acute Disease Quality Initiative) Group. J Am Heart Assoc. 2018;7(11):1-17. DOI: 10.1161/JAHA.118.008834

17. Vellinga S, Verbrugghe W, De Paep R, Verpooten GA, Janssen van Doom K. Identification of modifiable risk factors for acute kidney injury after cardiac surgery. Neth J Med. 2012;70 (10):450-4.

18. Traynor J, Mactier R, Geddes CC, Fox JG. How to measure renal function in clinical practice. Br Med J. 2006;333(7571): 733-7. DOI: 10.1136/bmj.38975.390370.7C

19. Bock JS, Gottlieb SS. Cardiorenal syndrome: new perspectives. Circulation. 2010;121(23):2592-600. DOI: 10.1161/CIRCULATIONAHA.109.886473

20. Wang Y, Bellomo R. Cardiac surgery-associated acute kidney injury: risk factors, pathophysiology and treatment. Nat Rev Nephrol.2017;13(11):697-711.DOI: 10.1038/nrneph.2017.119

21. Vermeulen Windsant IC, de Wit NC, Sertorio JT, van Bijnen AA, Ganushchak YM, Heijmans JH, et al. Hemolysis during cardiac surgery is associated with increased intravascular nitric oxide consumption and perioperative kidney and intestinal tissue damage. Front Physiol. 2014;5:340. DOI: 10.3389/ fphys.2014.00340

22. Zhang WR, Garg AX, Coca SG, Devereaux PJ, Eikelboom J, Pavsak P, et al. Plasma IL6 and IL10 concentrations predict AKI and long-term mortality in adults after cardiac surgery. J Am Soc Nephrol. 2015;26(12):3123-32. DOI: 10.1681/ ASN.2014080764

23. Thiele RH, Isbell JM, Rosner MH. AKI associated with cardiac surgery. Clin J Am Soc Nephrol. 2015;10(3):500-14. DOI: 10.2215/CJN.07830814
24. Coleman MD, Shaefi S, Sladen RN. Preventing acute kidney injury after cardiac surgery. Curr Opin Anaesthesiol. 2011;24 (1):70-6. DOI: 10.1097/ACO.0b013e3283422ebc

25. Coppolino G, Presta P, Saturno L, Fuiano G. Acute kidney injury in patients undergoing cardiac surgery. J Nephrol. 2013; 26(1):32-40. DOI: 10.5301/jn.5000215

26. Khan UA, Coca SG, Hong K, Koyner JL, Garg AX, Passik CS, et al. Blood transfusions are associated with urinary biomarkers of kidney injury in cardiac surgery. J Thorac Cardiovasc Surg. 2014;148(2):726-32. DOI: 10.1016/j.jtcvs.2013.09.080

27. Lamy A, Devereaux PJ, Prabhakaran D, Taggart DP, Hu S, Paolasso E, et al. Effects of off-pump and on-pump coronaryartery bypass grafting at 1 year. N Engl J Med. 2013;368 (13):1179-88. DOI: 10.1056/NEJMoa1301228

28. Shroyer AL, Grover FL, Hattler B, Collins JF, McDonald GO, Kozora E, et al. On-pump versus off-pump coronary-artery bypass surgery. N Engl J Med. 2009;361(19):1827-37. DOI: 10.1056/NEJMoa0902905

29. Deininger S, Hoenicka M, Müller-Eising K, Rupp P, Liebold A, Koenig W, et al. Renal function and urinary biomarkers in cardiac bypass surgery: a prospective randomized trial comparing three surgical techniques. Thorac Cardiovasc Surg. 2016; 64(7):561-8. DOI: $10.1055 / \mathrm{s}-0035-1567871$

30. Thakar CV, Arrigain S, Woley S, Yared JP, Paganini EP. A clinical score to predict acute renal failure after cardiac surgery. J Am Soc Nephrol. 2005;16(1):162-8. DOI: 10.1681/ASN. 2004040331

31. Mehta RH, Grab JD, O’Brien SM, Bridges CR, Gammie JS, Haan CK, et al. Bedside tool for predicting the risk of postoperative dialysis in patients undergoing cardiac surgery. Circulation. 2006;114(21):2208-16. DOI: 10.1161/CIRCULATIONAHA.106.635573

32. Wijeysundera DN, Karkouti K, Dupuis JY, Rao V, Chan CT, Granton JT, et al. Derivation and validation of a simplified predictive index for renal replacement therapy after cardiac surgery. JAMA. 2007;297(16):1801-9. DOI: 10.1001/jama. 297.16.1801

33. Huen SC, Parikh CR. Predicting acute kidney injury after cardiac surgery: a systematic review. Ann Thorac Surg. 2012;93 (1):337-47. DOI: 10.1016/j.athoracsur.2011.09.010

34. Birnie K, Verheyden V, Pagano D, Bhabra M, Tilling K, Sterne $\mathrm{JA}$, et al. Predictive models for kidney disease: improving global outcomes (KDIGO) defined acute kidney injury in UK cardiac surgery. Crit Care. 2014;18(6):606. DOI: 10.1186/s13054014-0606-x

35. Klisic A, Kavaric N, Bjelakovic B, et al. Cardiovascular risk assessed by Reynolds risk score in relation to waist circumference in apparently healthy middle-aged population in Montenegro. Acta Clin Croat. 2018;57(1):22-30. DOI: 10.20471/acc.2018. 57.01 .03

36. Lameire N, Kellum J, KDIGO AKI Guideline Work Group. Contrast-induced acute kidney injury and renal support for acute kidney injury: a KDIGO summary (Part 2). Crit Care. 2013;17(1):205. DOI: 10.1186/cc11455 
37. Antonic M. Effect of ascorbic acid on postoperative acute kidney injury in coronary artery bypass graft patients: a pilot study. Heart Surg Forum. 2017;20(5):214-8. DOI: 10.1532/hsf.1811

38. Bailey M, McGuinness S, Haase M, Haase-Fielitz A, Parke R, Hodgson CL, et al. Sodium bicarbonate and renal function after cardiac surgery: a prospectively planned individual patient meta-analysis. Anesthesiology. 2015;122(2):294-306. DOI: 10.1097/ALN.0000000000000547

39. Yang B, Xu J, Xu F, Zou Z, Ye C, Mei C, et al. Intravascular administration of mannitol for acute kidney injury prevention: a systematic review and meta-analysis. PLoS One. 2014;9(1):ID e85029.

40. Scrascia G, Guida P, Rotunno C, de Luca Tupputi Schinosa L, Paparella D. Anti-inflammatory strategies to reduce acute kidney injury in cardiac surgery patients: a meta-analysis of randomized controlled trials. Artif Organs. 2014;38(2):101-12. DOI: 10.1111 /aor.12127

41. Vandewiele K, De Somer F, Vandenheuvel M, et al. The impact of cardiopulmonary bypass management on outcome: a propensity matched comparison between minimally invasive and conventional valve surgery. Interact Cardiovasc Thorac Surg. 2020. DOI: https://doi.org/10.1093/icvts/ivaa052

42. Haldenwang P, Trampisch M, Schlömicher M, et al. Risk factors for acute kidney injury following TA-TAVI or minimally invasive aortic valve replacement: which procedure is less kidney damaging in elderly patients? Thorac Cardiovasc Surg. 2014;62(6):482-8. DOI: 10.1055/s-0034-1376201

43. Ricklefs M, Heimeshoff J, Hanke JS, et al. The influence of less invasive ventricular assist device implantation on renal function. J Thorac Dis. 2018;10:1737-42. DOI: 10.21037/ jtd.2017.10.03
44. VA/NIH Acute Renal Failure Trial Network, Palevsky PM, Zhang JH, O'Connor TZ, Chertow GM, Crowley ST, et al. Intensity of renal support in critically ill patients with acute kidney injury. N Engl J Med. 2008;359(1):7-20. DOI: 10.1056/ NEJMoa0802639

45. RENAL Replacement Therapy Study Investigators, Bellomo R, Cass A, Cole L, Finfer S, Gallagher L, et al. Intensity of continuous renal-replacement therapy in critically ill patients. N Engl J Med. 2009;361(17):1627-38. DOI: 10.1056/NEJMoa0902413

46. Redzek A, Mironicki M, Gvozdenovic A, Petrovic M, Cemerlic-Ađic N, Ilic A, et al. Predictors for hospital readmission after cardiac surgery. J Card Surg. 2015;30(1):1-6. DOI: 10.1111/jocs. 12441

47. Antonic M. Preoperative renal dysfunction is a predictor of postoperative atrial fibrillation in coronary artery bypass patients. Acta Medico-Biotechnica. 2019;12(2):29-38. DOI: URN:NBN:SI:DOC-MQG8Q1L8

48. Gabaldo K, Sutlic Z, Miskovic D, et al. Postpericardiotomy syndrome incidence, diagnostic and treatment strategies: experience at two collaborative centers. Acta Clin Croat. 2019; 58(1):57-62. DOI: 10.20471/acc.2019.58.01.08

49. Billings FT, Shaw AD. Clinical trial endpoints in acute kidney injury. Nephron Clin Pract. 2014;127(1-4):89-93. DOI: $10.1159 / 000363725$

50. Ferreiro A, Lombardi R. Acute kidney injury after cardiac surgery is associated with mid-term but not long-term mortality: a cohort-based study. PLoS One. 2017;12(7): e0181158. DOI: 10.1371/journal.pone. 0181158

Sažetak

\section{AKUTNO BUBREŽNO OŠTEĆENJE NAKON OPERACIJA NA OTVORENOM SRCU}

\section{A. Djordjević, S. Šušak, L. Velicki i M. Antonič}

Akutno bubrežno oštećenje povezano s kardiokirurgijom (cardiac surgery-associated acute kidney injury, CS-AKI) je značajna komplikacija s visokim pobolom i smrtnošću. Postoji više dijagnostičkih kriterija za dijagnozu CS-AKI. Usprkos mnogim novim istraživanjima, kreatinin i ureja ostaju temelj dijagnostike. Glavni patofiziološki procesi koji doprinose bubrežnom oštećenju su bubrežna hipoperfuzija, upala uzrokovana oksidativnim stresom i bubrežno oštećenje uzrokovano upotrebom nefrotoksičnih sredstava. Tijekom terapije može se utjecati na nekoliko čimbenika rizika (upotreba nefrotoksičnih sredstava, trajanje kardiopulmonarne premosnice, tip izvantjelesne cirkulacije, smanjeni minutni volumen ili poslijeoperacijska hipotenzija). Cilj prevencije AKI je spriječiti progresiju bubrežnog oštećenja koje zahtijeva kompleksniju terapiju i donosi lošije dugoročne ishode.

Ključne riječi: Bubrežno oštećenje; Kardiokirurgija; Perfuzija; Oksidativni stres; Dijaliza 